\title{
Thyroid Function in Children with Idiopathic Nephrotic Syndrome
}

\author{
Aparup Kanti Das ${ }^{1 *}$ \\ Tanuka Barua ${ }^{2}$ \\ Dipika Dey² \\ Minakshi Roy ${ }^{3}$ \\ Zabeen Choudhury ${ }^{4}$ \\ Mohammed Rezaul Karim²
}

'Department of Paediatrics Boalkhali Upazila Health Complex Chattogram, Bangladesh.

${ }^{2}$ Department of Paediatrics Chattogram Maa-O-Shishu Hospital Medical College Chattogram, Bangladesh.

${ }^{3}$ Department of Radiology \& Imaging 250 Beded District Sadar Hospital

Cox's Bazar, Bangladesh.

${ }^{4}$ Department of Paediatrics Chattogram Medical College

Chattogram, Bangladesh.
*Correspondence to:

\section{Dr Aparup Kanti Das}

Junior Consultant

Department of Paediatrics

Boalkhali Upazila Health Complex

Chattogram, Bangladesh.

Mobile: +8801712014013

Email: draparup33@gmail.com

Date of Submission : $\quad 07.10 .2019$

Date of Acceptance $\quad$ : $\quad 20.12 .2019$

www.banglajol.info/index.php/CMOSHMCJ

\begin{abstract}
Background: The underlying abnormality in nephrotic syndrome is an increase in permeability of the glomerular membrane. Urinary loses of binding proteins such as Thyroxine Binding Globulin (TBG) albumin results in a reduction in serum thyroxine $\left(T_{4}\right)$ and sometimes in total $T_{3}$ levels. The study was done to assess thyroid hormone status of idiopathic nephrotic syndrome patients at diagnosis, compare the thyroid function after treatment with steroid, correlate with serum albumin and compare the thyroid function with control group.
\end{abstract}

Materials and methods: It was an analytic type of cross sectional study, done in Paediatric ward, Chittagong Medical College Hospital, Chattogram from 01.05.11 to 30.11.11. Total 58 patients in two groups were included. In group A 32 cases of idiopathic nephrotic syndrome patients and in group B 26 control cases of same age and sex were taken. In group A thyroid function was done at initial diagnosis and in hypothyroid patients in this group again thyroid function was done after treatment with steroid. Data was collected through interviewing with pre-designed questionnaire, physical examination and investigation techniques.

Results: Thyroid hormone level of nephrotic children were significantly lower than that of control group. Nephrotic children with thyroid hypofunction were found euthyroid after initial treatment with steroid that was statistically significant and there was positive correlation between serum albumin and thyroid hormone level.

Conclusion: Children suffering from nephrotic syndrome had significant thyroid hypofunction because of low serum albumin level and after treatment with steroid they became euthyroid.

Key words: Nephrotic syndrome; Thyroid function; Hypothyroid.

\section{INTRODUCTION}

Nephrotic syndrome is primarily a pediatric kidney disorder characterized by massive proteinuria, hypoalbuminemia, edema and hyperlipidemia with an incidence in Paediatric population is 2-3/100,000 children per year ${ }^{1}$. Most common form of nephrotic syndrome in pediatric age group is idiopathic nephrotic syndrome.

We know that kidney is involved in the metabolism and elimination of thyroid hormone. The interactions between kidney and thyroid functions are known for years ${ }^{2-5}$. From a clinical practice viewpoint, it should be mentioned that both hypothyroidism and hyperthyroidism are accompanied by remarkable alterations in the metabolism of water and electrolyte ${ }^{6,7}$. The decline in kidney function is accompanied by changes in the synthesis, secretion, metabolism, and elimination of $\mathrm{TH}^{8}$.

Nephrotic syndrome is also associated with changes in serum thyroid hormome levels ${ }^{9-12}$. Urinary losses of binding proteins, such as Thyroxine Binding Globulin 
(TBG) transthyretin or prealbumin, albumin and TH binded to them, result in a reduction in serum total thyroxine $\left(\mathrm{T}_{4}\right)$ and sometimes, in total $\mathrm{T}_{3}$ levels. These hormonal changes are related both to the degree of proteinuria and to serum albumin levels. However patients often remain euthyroid, because free $\mathrm{T}_{4}$ and $\mathrm{T}_{3}$ levels are usually normal. This suggests that thyroid is able to compensate for hormonal urinary losses keeping the patient euthyroid. However, in patients with low thyroid reserve overt hypothyroidism can develop. Nephrotic syndrome may increase the exogenous levothyroxine needs in patients with hypothyroidism ${ }^{13,14}$.

This study is to find out thyroid hormone status of idiopathic nephrotic syndrome patients at diagnosis, compare the thyroid function after treatment with steroid, correlate with serum albumin and compare the thyroid function with control group.

\section{MATERIALS AND METHODS}

This was analytic type cross sectional study conducted from May, 2011 to November, 2011 at the Paediatric Ward, Chattogram Medical College Hospital, Chattogram. Idiopathic nephrotic syndrome cases aged 2-6 years with typical presentation, diagnosed by positive heat coagulation test, low serum albumin $(<2.5 \mathrm{~g} / \mathrm{dl})$ and high serum cholesterol $(>250$ $\mathrm{mg} / \mathrm{dl}$ ) first morning protein creatinine ratio ( $>2 \mathrm{mg}$ protein $/ \mathrm{mg}$ creatinine) or 24 hours total urinary protein $\left(>40 \mathrm{mg} / \mathrm{m}^{2} / \mathrm{hr}\right)$ were included in this study. Children less than 2 yrs of age and more than 6 yrs of age, nephrotic syndrome due to secondary causes and nephrotic syndrome with atypical presentation like hypertension, gross haematuria were excluded. Informed written consent was taken from parents or legal guardian of these patients for serum $\mathrm{T}_{3}, \mathrm{~T}_{4}, \mathrm{TSH}$ test to be done. Heat coagulation test was done and interpretation was recorded in every patients. After confirmation of diagnosis, blood was sent for serum $\mathrm{T}_{3}, \mathrm{~T}_{4}, \mathrm{TSH}$ and results were recorded in data collection sheet and steroid started according to standard regimen. For initial attack $-60 \mathrm{mg} / \mathrm{m}^{2} /$ day in two divided dose for 6 weeks followed by $40 \mathrm{mg} / \mathrm{m}^{2} /$ day single morning dose alternate day for 6 weeks. These patients were categorized as Group A. 1 case in group A dropped out from the study who was found hypothyroid. After completion of 3 months treatment again serum $\mathrm{T}_{3}, \mathrm{~T}_{4}$, TSH was done only in those patients who were found hypothyroid. For control group cases were taken from NMC, Chattogram of same age group who came to do thyroid screening during study period. These patients were categorized as Group B. Data were analyze by IBM SPSS v.18.0. $\mathrm{Z}$ test, $\chi^{2}$ test, student $\mathrm{t}$ test and MannWhitney $U$ test and other test of significance was done where applicable to compose data. $\mathrm{p}<0.05$ was used as the minimum level of significance.

\section{RESULTS}

Total 32 nephrotic patients were included in Group A (Nephrotic children) and 26 cases in Group B (Control group). Mean age of our nephrotic children (Group A) and control group (Group B) was $4.53( \pm 1.34)$ years and $4.04( \pm 1.15)$ years that was not statistically significant $(p>0.05)$. Gender was matched in study subjects and control group $(71.9 \%$ vs $53.8 \%, \mathrm{p}>0.05$ ) (Table I).
Table I : Distribution of sex in both the study groups

\begin{tabular}{|c|c|c|c|c|c|c|c|c|}
\hline \multirow[t]{2}{*}{ SEX } & \multicolumn{6}{|c|}{ Study Groups } & \multirow{2}{*}{\multicolumn{2}{|c|}{$\chi^{2}$ value $\mathbf{p}$ value }} \\
\hline & n & $\%$ & n & $\%$ & n & $\%$ & & \\
\hline Male & 23 & 71.9 & 14 & 53.8 & 37 & 63.8 & & \\
\hline Female & 9 & 28.1 & 12 & 46.2 & 21 & 36.2 & 2.019 & $\mathrm{p}>0.05$ \\
\hline Total & 32 & 100.0 & 26 & 100.0 & 58 & 100.0 & & \\
\hline
\end{tabular}

Mean serum albumin was $1.81( \pm 0.44) \mathrm{gm} / 1$ and mean protein creatinine ratio was $4.85( \pm 0.81)$. More than half $(53.1 \%)$ of Group A (Nephrotic children) patients was found hypothyroid whereas only $19.2 \%$ of Group B (Control group) patients was hypothyroid that was statistically significant $(\mathrm{p}$ value $=0.008)$ (Table II). 1 case in Group A dropped out from the study who was found hypothyroid. Mean Serum $\mathrm{T}_{3}$, Serum $\mathrm{T}_{4}$, Serum TSH of Group A $(\mathrm{n}=32)$ were $1.21( \pm 0.63) \mathrm{nmol} / \mathrm{L}, 58.25( \pm$ $35.39) \mathrm{nmol} / \mathrm{L}, 5.55( \pm 3.20) \mathrm{nIU} / \mathrm{L}$ respectively whereas mean Serum $\mathrm{T}_{3}$, Serum $\mathrm{T}_{4}$ and Serum TSH of Group B (Control group) were $2.11( \pm 0.57) \mathrm{nmol} / \mathrm{L}, 114.56( \pm 36.45) \mathrm{nmol} / \mathrm{L}$, $3.08( \pm 1.68) \mathrm{nIU} / \mathrm{L}$ respectively. Comparison between two groups was statistically significant $(\mathrm{p}<0.001)$ (Table III).

Table III : Thyroid status on admission among the study groups

\begin{tabular}{|c|c|c|c|c|c|c|c|c|}
\hline & \multicolumn{6}{|c|}{ Study Groups } & \multirow{3}{*}{\multicolumn{2}{|c|}{$\chi^{2}$ value $p$ value }} \\
\hline & \multicolumn{2}{|c|}{ Group A } & \multicolumn{2}{|c|}{ Group B } & \multicolumn{2}{|c|}{ Total } & & \\
\hline & n & $\%$ & $\mathrm{n}$ & $\%$ & $\mathrm{n}$ & $\%$ & & \\
\hline Euthyroid & 15 & 46.9 & 21 & 80.8 & 36 & 62.1 & 7.000 & 0.008 \\
\hline Hypothyroid & 17 & 53.1 & 5 & 19.2 & 22 & 37.9 & & $\begin{array}{l}\text { gnificant } \\
(<0.01)\end{array}$ \\
\hline Total & 32 & 100.0 & 26 & 100.0 & 58 & 100.0 & & \\
\hline
\end{tabular}

Table III : Thyroid hormone assay on admission among the study groups

\begin{tabular}{lllllllll}
$\begin{array}{l}\text { Thyroid Status Study } \\
\text { on Admission } \\
\text { Serum } \mathrm{T}_{3}\end{array}$ & Groups & & MEAN & \pm SD & MEDIAN RANGE & SIGN. \\
(nmo//L) & Group A & 32 & 1.21 & 0.63 & 1.20 & $0.16-2.44$ & $\mathrm{t}=4.648$ \\
& Group B & 15 & 2.11 & 0.57 & 1.90 & $1.38-3.06$ & $\mathrm{p}<0.001$ \\
Serum T $_{4}$ & & & & & & & \\
$(\mathrm{nmol} / \mathrm{L})$ & Group A & 32 & 58.25 & 35.39 & 55.00 & $12-150$ & $\mathrm{t}=5.343$ \\
& Group B & 18 & 114.56 & 36.45 & 119.00 & $66-163$ & $\mathrm{p}<0.001$ \\
Serum TSH & & & & & & & \\
(nIU/L) & Group A & 32 & 5.55 & 3.20 & 4.68 & $0.47-12.03$ & $\mathrm{t}=3.781$ \\
& Group B & 26 & 3.08 & 1.68 & 2.76 & $0.48-6.25$ & $\mathrm{p}<0.001$ \\
\hline
\end{tabular}

Among hypothyroid cases $(n=16)$ before treatment mean Serum $\mathrm{T}_{3}$, mean Serum $\mathrm{T}_{4}$ and mean Serum TSH were 0.76 $( \pm 0.28) \mathrm{nmol} / \mathrm{L}, 32.87( \pm 18.84) \mathrm{nmol} / \mathrm{L}$ and $7.55( \pm 2.49) \mathrm{nIU} / \mathrm{L}$ respectively. After treatment with steroid, mean Serum $\mathrm{T}_{3}$, mean Serum $\mathrm{T}_{4}$ level significantly increaed and mean Serum TSH significantly reduced that became $2.32( \pm 0.71) \mathrm{nmol} / \mathrm{L}$, $124.06( \pm 40.62) \mathrm{nmol} / \mathrm{L}$ and $2.45( \pm 1.36) \mathrm{nIU} / \mathrm{L}$ respectively ( $\mathrm{p}<0.001$ in comparison with group B. (Table IV). 
Table IV : Thyroid hormone assay before and after treatment in hypothyroid cases

$\begin{array}{lllllll}\text { Thyroid Status in group A } & \mathrm{n} & \text { MEAN } & \pm \text { SD } & \text { t value } & \mathrm{p} \text { value } \\ \text { Serum T3 } & \text { Before Treatment } & 16 & 0.76 & 0.28 & 8.677 & \mathrm{p}<0.001 \\ & \text { After Treatment } & & 2.32 & 0.71 & & \\ \text { Serum T }_{4} & \text { Before Treatment } & 16 & 32.87 & 18.84 & 9.015 & \mathrm{p}<0.001 \\ & \text { After Treatment } & & 124.06 & 40.62 & & \\ \text { Serum TSH } & \text { Before Treatment } & 16 & 7.55 & 2.49 & 8.351 & \mathrm{p}<0.001 \\ & \text { After Treatment } & & 2.45 & 1.36 & & \end{array}$

There was significant correlation between serum albumin $(1.81 \pm 0.44 \mathrm{gm} / \mathrm{l})$ and thyroid hormone (T3 $1.21 \pm 0.63 \mathrm{nmol} / \mathrm{L}$, T4 $58.25 \pm 35.39 \mathrm{nmol} / \mathrm{L}, 5.55 \pm 3.20 \mathrm{mIU} / \mathrm{L})$ of Group A (Nephrotic children) on admission (For $\mathrm{T}_{3}=\mathrm{p}<0.05, \mathrm{~T}_{4}=\mathrm{p}<0.01$, $\mathrm{TSH}=\mathrm{p}<0.001$ ). (Table V, Figure 1, 2, 3).

Table V : Correlations between serum albumin and thyroid hormones in the study groups A

\begin{tabular}{|c|c|c|c|c|}
\hline $\begin{array}{l}\text { Correlations } \\
\text { Between }\end{array}$ & & $\mathrm{n}$ & $\begin{array}{l}\text { Pearson's } \\
\text { Coefficient (r) } \\
\text { Correlation }\end{array}$ & p \\
\hline Serum Albumin & $\begin{array}{l}\text { Serum } \mathrm{T}_{3} \text { on } \\
\text { Admission } \\
\text { Serum } \mathrm{T}_{4} \text { on } \\
\text { Admission } \\
\text { Serum TSH on } \\
\text { Admission }\end{array}$ & 32 & $\begin{array}{l}0.519 \\
-0.610\end{array}$ & $\begin{array}{l}p<0.05 \\
p<0.01 \\
p<0.001\end{array}$ \\
\hline 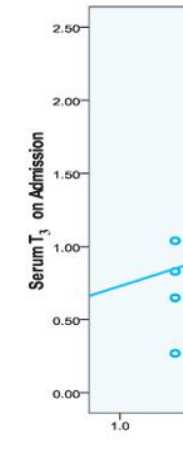 & (2) & ० & dil.5 & Lnear $=0.172$ \\
\hline
\end{tabular}

Figure 1 : Scatter plots showing correlation between serum albumin and serum $\mathrm{T}_{3}$ in the study groups $\mathrm{A}$

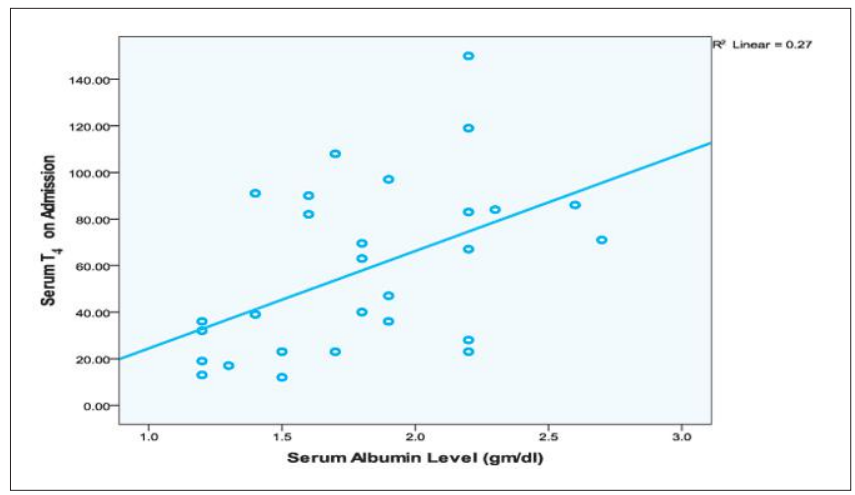

Figure 2 : Scatter plots showing correlation between serum albumin with serum $\mathrm{T}_{4}$ in the study Group A

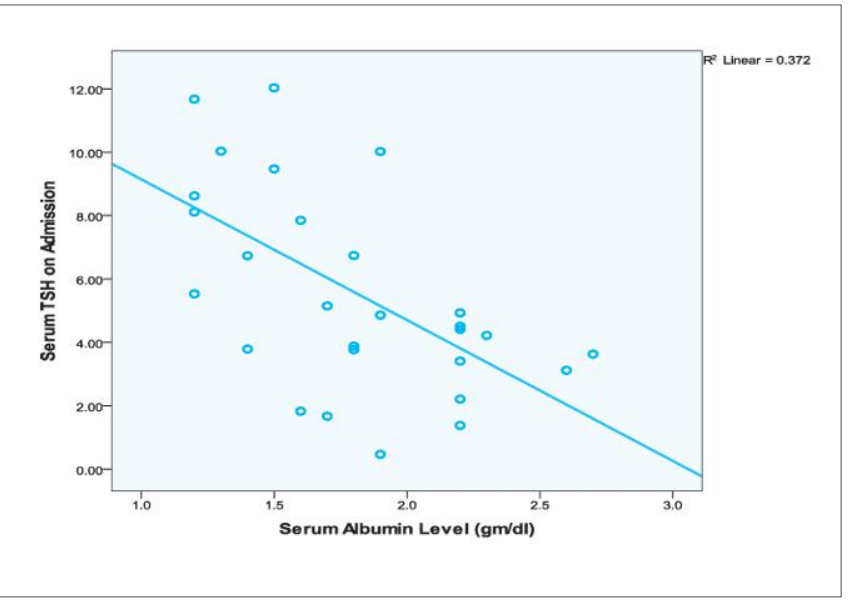

Figure 3 : Scatter plots showing correlation between serum albumin with serum TSH in the study Group A

\section{DISCUSSION}

Nephrotic syndrome is associated with changes in serum thyroid hormone levels. Urinary loses of binding protein and thyroid hormone binded to them, result in a reduction in serum total Thyroxine $\left(\mathrm{T}_{4}\right)$ and total $\mathrm{T}_{3}$ levels. These hormonal changes are related both to the degree of proteinuria and to serum albumin levels. However patient often remain euthyroid, because free $T_{4}$ and $T_{3}$ levels are usually normal. In this study we have observed this status of thyroid function with idiopathic nephrotic syndrome at initial diagnosis, compare the thyroid function with control group, compare the thyroid function after treatment with steroid and correlate with serum albumin level.

In this study, male preponderance was noted like many other studies ${ }^{15}$. More than half $(53.1 \%)$ of nephrotic children were hypothyroid similar to Nuhad Ismail ${ }^{16}$. Due to urinary loses of Thyroxine Binding Globulin (TBG) and other thyroid binding protein (transthyretin and albumin) and thyroid hormone bound to them result in a low total concentrations.

After treatment with steroid, nephrotic children with hypothyroid state became euthyroid. This findings is consistent with the results of RD Utigel ${ }^{17}$. This may be due to the repaired glomerular filtration barrier after treatment that results in reduced proteinuria and so increased serum protein binding of thyroid hormone after the rise of protein level.

We found a positive correlation between serum albumin and serum T3, T4, TSH. RD Utigel in his study conducted in England found decreased serum T3, T4 and increased serum TSH in relation to serum albumin which is consistent with this study $^{17}$.

As it has been stated earlier the research hypothesis, children suffering from nephrotic syndrome have significant thyroid hypofunction due to low serum albumin level because of massive proteinuria has been established with the study.

\section{CONCLUSION}

Considering all above finding it may be concluded that children suffering from idiopathic nephrotic syndrome have significant thyroid hypofunction because of low serum albumin. This hypofunction is transient as treatment with steroid thyroid function becomes normal. 


\section{RECOMMENDATIONS}

Though significant thyroid hypofunction was found in idiopathic nephrotic syndrome patients on initial diagnosis, when proteinuria resolved they became euthyroid. As in the present study sample size small, larger further study is recommended to find out the clinical correlation of nephrotic syndrome patient with thyroid function.

\section{DISCLOSURE}

All the authors declared no competing interest.

\section{REFERENCES}

1. Behrman RE, Kliegman RM, Jenson HB. Nelson Textbook of Pediatrics $18^{\text {th }}$ ed. India: WB Saunders Co. 2009; 2190-2195.

2. Feinstein EI, Kaptein EM, Nicoloff JT et al. Thyroid function in patient with nephrotic syndrome and normal renal function. American Journal of Nephrology.1982; 2: 70-76.

3. Kaptein EM, Feinstein EI, Massry SG. Thyroid hormone metabolism in renal diseases. Contributions to Nephrology.1982;33:122-135.

4. Junglee NA, Scanlon MF, Rees DA. Increasing thyroxine requirements in primary hypothyroidism, don't forget the urinalysis. Journal of Postgraduate Medicine. 2006; 52: 201-203.

5. Kaptein EM, Hoopes MT, Pariser AD. rT3 metabolism in patient with nephrotic syndrome and normal GFR compared with normal subjects. American Journal of Physiology.1991; 260:E641-E650

6. Katz AI, Lindheimer MD. Actions of hormones on kidney. Annual review of Physiology.1977; 39: 97-133

7. Katz AI, Emmanouel DS, Lindheimer MD.Throid hormone and the kidney. Nephron.1975; 15: 223-249.

8. $\quad$ Kaptein EM,Verde HQ, Chooljian CJ et al. The thyroid in end stage renal disease. Medicine.1988; 67: 187-197.

9. Holmberg C, Tryqqvason K Kestila MK et al. Congenital nephrotic syndrome. In: Avner E, Harmon W, Niauder P (Editors). Pediatric Nephrology, $5^{\text {th }}$ ed. Philadelphia, Lippincortt Williams and Wilkins. 2004; 503-516.

10. Mctaggart SJ, Algar E, Chow CW et al. Clinical spectrum of Denys-Drash and Frasier syndrome. Pediatr Nephrol. 2001;16: 335-339.

11. Junglee NA, Scanlon MF, Rees DA. Increasing thyroxine requirements in primary hypothyroidism. Journal of postgraduate Medicine. 2006;52:201-203

12. Kaptein EM, Hoopes MT, rT3 metabolism in patients with nephrotic syndrome and normal GFR composed with normal subject. Americal Journal of Physiology. 1991;260:E614-E650

13. Jungle NA, Scanlon MF, Rees DA. Increasing thyronine requirements in primary hypothyroidism: Don't forget the urinalysis, Journal of postgraduate Medicine. 2006;52:201-203.

14. Utigel RD. Altered thyroid function in nonthyroidal illness: To treat or not? N Engl J Med. 1995; 333:1562-1563.

15. Hossain M M, Ara H, Khan M R. A study of nephrotic syndrome in children at IPGMR. Bang Peditr. !982;6(1):25-28.

16. Ismail N. Endocrine dysfunction in the nephrotic syndrome. Review version. 2005.

17. Utigel RD. Nephrotic syndrome associated with thyroid dysfunction in clinical observation. Posted: 2010. 